\title{
Pengaruh Penambahan Serum Dan Lama Waktu Inkubasi Lateks Terhadap Aktivitas Fagositosis Makrofag Tikus Sprague Dawley (SD) Dalam Menunjang Kegiatan Penelitian
}

\author{
Istini $^{1}$, Raden budisantoso ${ }^{2}$ \\ ${ }^{1}$ Laboratorium Penelitian dan Pengujian Terpadu Universitas Gadjah Mada, Yogyakarta \\ istini@ugm.ac.id \\ ${ }^{2}$ Laboratorium Akuakultur Departemen Perikanan Fakultas Pertanian Universitas Gadjah Mada, \\ Yogyakarta \\ raden.budisantoso@ugm.ac.id
}

\begin{abstract}
ABSTRAK
Fagositosis makrofag peritoneal dari hewan coba merupakan salah satu penelitian yang berkaitan dengan sistem imun tubuh. Fagositosis merupakan reaksi makrofag memfagosit/memakan lateks, tetapi reaksi tersebut kadang terkendala karena lateks tidak difagosit oleh makrofag. Perlu penambahan serum normal dari hewan coba bersangkutan, namun waktu inkubasi masih belum optimal. Penelitian ini bertujuan untuk mengetahui pengaruh penambahan serum pada lateks dan lama waktu inkubasi sehingga terjadi reaksi fagositosis yang optimal untuk selanjutnya dapat dipakai peneliti sebagai patokan dalam bekerja. Waktu inkubasi menggunakan 5 perlakuan : (1) makrofag + lateks tanpa serum inkubasi 60 menit, (2) makrofag + lateks + serum inkubasi 60 menit, (3) makrofag + lateks + serum inkubasi 45 menit, (4) makrofag + lateks + serum inkubasi 30 menit, (5) makrofag + lateks + serum inkubasi 15 menit. Hasil penelitian menunjukkan bahwa waktu penambahan lateks yang mengandung serum dan diinkubasi selama 60 menit dan 45 menit yaitu lateks yang difagosit oleh makrofag terlalu banyak, sedangkan untuk waktu inkubasi 30 menit dan 15 menit lateks yang difagosit makrofag tidak terlalu banyak. Kesimpulan: apabila penelitian fagositosis makrofag dari tikus Sprague Dawley(SD) dengan lateks mengalami kendala yaitu lateks tidak di fagosit oleh makrofag maka dapat ditambahkan serum pada lateks, sedangkan waktu inkubasi makrofag dengan lateks yang mengandung serum selama 15-30 menit
\end{abstract}

Kata kunci : Fagositosis, Makrofag, Lateks, Serum

\section{PENDAHULUAN}

Sistem imun atau sistem kekebalan tubuh adalah mekanisme pertahanan tubuh yang bertugas merespon serangan dari luar tubuh kita, apabila sistem imun tidak bekerja optimal, tubuh akan rentan terhadap penyakit. Banyak cara digunakan untuk meningkatkan sistem kekebalan tubuh, salah satunya melalui bahan atau senyawa yang berfungsi sebagai imunomodulator (meningkatkan sistem imun tubuh). Makrofag merupakan salah satu sel yang berperan penting dalam respon imun, baik perperan fungsional dalam fagositosis maupun perannya sebagai antigen presenting cells (APC) (Kusmardi, dkk, 2006). Fagositosis makrofag merupakan salah satu penelitian yang sering di lakukan oleh peneliti, meliputi penelitian skripsi, tesis, desertasi maupun penelitian proyek bagi dosen. Fagositosis sebagian besar diperankan oleh makrofag, sebab kemampuan fagositosisnya jauh lebih kuat dibandingkan sel fagosit yang lain. Fagositosis merupakan proses penelanan yang dilanjutkan dengan pencernaan seluler terhadap bahanbahan asing yang digantikan lateks masuk ke dalam tubuh oleh sel makrofag. Tetapi reaksi fagositosis antara makrofag dengan lateks yang dilakukan dalam waktu 1 jam atau 60 menit kadang tidak terjadi sehingga hasil pengamatan yaitu makrofag tidak memfagosit lateks atau kosong, hal ini sangat merugikan peneliti karena harus mengulang penelitiannya dari awal. Persoalan tersebut dapat diatasi dengan penambahan serum pada lateks sebelum direaksikan dengan makrofag dengan waktu yang telah ditentukan yaitu 1 jam atau 60 menit, akan tetapi hasil 
pengamatan lateks yang difagosit makrofag terlalu banyak dan terlalu padat sehingga mempersulit pembacaan hasil. Perlu dilakukan penelitian untuk mendapatkan waktu reaksi yang optimal supaya reaksi antara makrofag dengan lateks sesuai yang diharapkan. Serum dapat membantu mempermudah proses pelekatan lateks terhadap makrofag oleh karena proses opsonisasi yaitu proses pelapisan partikel antigen oleh antibodi yang terdapat di dalam serum darah (Robbins dan Kumar, 1995; Susanti dan Rahayuningsih, 2003 sit. Pratiwi, 2014). Komplemen merupakan salah satu sistem enzim serum yang berfungsi antara lain untuk lisis bakteri, opsonisasi yang meningkatkan fagositosis partikel antigen, mengikat reseptor komplemen spesifik pada sel sistem imun sehingga memicu fungsi sel spesifik untuk memproduksi antibodi (Baratawidjaya dan Rengganis, 2009 sit. Izzati, 2014). Makrofag merupakan sel fagosit mononuklear yang utama di jaringan dalam proses fagositosis terhadap mikroorganisme dan kompleks molekul asing lainnya. Makrofag diproduksi di sumsum tulang belakang dari sel induk mieloid yang mengalami proliferasi dan dilepaskan ke dalam darah sesudah atau satu periode melalui fase monoblas-fase promonosit-fase monosit. Monosit yang telah meninggalkan sirkulasi darah akan mengalami perubahan-perubahan untuk kemudian menetap di jaringan sebagai makrofag (Ukhrowi, 2011). Makrofag peritoneal secara bebas berada dalam cairan peritoneum. Keberadaan makrofag sepanjang kapiler memungkinkan untuk menangkap patogen dan antigen yang masuk ke dalam tubuh (Baratawidjaja, 2009).

Sel yang berperan dalam respon imun alamiah terdiri dari sel fagosit (makrofag dan neutrofil) dan sel NK (natural killer). Respons makrofag terhadap mikroba hampir sama cepatnya dengan neutrofil, tetapi makrofag lebih lama hidup daripada neutrofil. Fagositosis makrofag

\section{METODE PENELITIAN}

\section{Bahan dan alat penelitian}

Gunting, pinset, sarung tangan, masker, spuit $10 \mathrm{ml}$, tabung $15 \mathrm{ml}$, tabung $1,5 \mathrm{ml}$, pipet tetes, mikropipet, tip kuning, tip biru, mikroplate 24 sumuran, coverslip juga lebih aktif dalam menghadapi patogen seperti mikroorganisme maupun antigen lain bahkan sel atau jaringan sendiri yang mengalami kerusakan atau mati, sehingga makrofag dapat dikategorikan sebagai sel efektor utama pada respon imun alamiah. Kemampuan (daya) fagositosis makrofag sangat penting dalam menghadapi patogen mikroorganisme maupun sel dan jaringan sendiri yang telah rusak, sehingga makrofag dapat dikatakan sebagai professional phagocytic cell (Abbas et al., 2008).

Lateks adalah getah kental menyerupai susu yang dihasilkan banyak tumbuhan dan membeku ketika terkena udara bebas. Beberapa hifa jamur juga diketahui menghasilkan cairan kental mirip lateks. Pada tumbuhan, lateks diproduksi oleh sel-sel yang membentuk suatu pembuluh tersendiri yang disebut pembuluh lateks. Sel-sel ini berada di sekitar pembuluh tapis (floem) dan memiliki inti banyak dan memproduksi butiran-butiran kecil lateks di bagian sitosolnya, apabila jaringan pembuluh sel ini terbuka misalnya karena keratan maka akan terjadi proses pelepasan butiran-butiran ini ke pembuluh dan keluar sebagai getah kental (Anonim, 2010).

Serum dalam darah atau blood serum adalah komponen yang bukan berupa sel darah, juga bukan faktor koagulasi; serum adalah plasma darah tanpa fibrinogen, Serum terdiri dari semua protein (yang tidak digunakan untuk pembekuan darah). Rumusan umum serum yaitu serum = plasma - fibrinogen - protein faktor koagulasi (Anonim, 2010). Terdapat dua jenis protein utama dalam serum, yaitu albumin dan globulin. Albumin adalah salah satu komponen serum yang sering diuji. Tujuan penelitian ini adalah untuk mengetahui pengaruh penambahan serum pada lateks dan lama waktu inkubasi pemberian lateks yang mengandung serum terhadap aktivitas fagositosis makrofag peritoneal dari tikus Sprague Dawley $(S D)$ supaya mendapatkan reaksi fagositosis yang optimal.

bulat, hemocytometer, mikroskop, kamera foto, Biosafety cabinet class II, sentrifus dingin, inkubator $\mathrm{CO}_{2}$.

Ketamin, Xylaxin, Alkohol 70\%, media Roswell Park Memorial Institute(RPMI)-1640, Fetal Bovine 
Serum(FBS), penicillin-streptomicin 1\%, fungizon $0,5 \%$, Latex beads polystyrene $3 \mu \mathrm{m}$, Phosphat Buffer Saline(PBS), Metanol absolut, Giemsa 20\%, Akuades.

Metode yang digunakan ialah kultur sel makrofag dari peritoneal. Tikus dibius kemudian dilakukan dislokasi pada leher selanjutnya tikus dibedah dan diambil makrofagnya lewat peritoneal. Sel yang diperoleh kemudian ditampung dan disentrifus dengan kecepatan $1200 \mathrm{rpm}$ selama 10 menit pada suhu $4{ }^{\circ} \mathrm{C}$. Sel makrofag dihitung dengan kepadatan $2,5 \times 10^{6} \mathrm{sel} / \mathrm{ml}$ dan dikultur diatas coverslip dalam plate 24 sumuran lalu di inkubasi dalam inkubator $\mathrm{CO}_{2}$ pada suhu $37{ }^{\circ} \mathrm{C}$ selama 30 menit, kemudian tambahkan medium hingga $1 \mathrm{ml}$. Inkubasi sel dalam inkubator $\mathrm{CO}_{2}$ pada suhu $37{ }^{\circ} \mathrm{C}$ selama 2 jam. Sel dicuci menggunakan medium RPMI dan ditambah medium komplit sebanyak $1 \mathrm{ml}$. Inkubasi kembali sel dalam inkubator $\mathrm{CO}_{2}$ pada suhu $37{ }^{\circ} \mathrm{C}$ selama 24 jam. Siapkan lateks dengan kepadatan $2,5 \times 10^{6}$ lateks/ml tanpa penambahan serum sesuai prosedur yang sudah baku, perlakuan ini merupakan perlakuan (1) dan menjadi pembanding bagi keempat perlakuan lainnya. Siapkan tabung lain yang berisi lateks sesuai

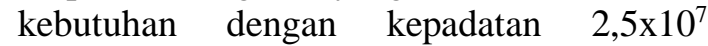
lateks/ml kemudian tambahkan serum nornal tikus $S D$ sebanyak $1 \mathrm{ml}$ lalu diinkubasi pada suhu $37{ }^{\circ} \mathrm{C}$ selama 60 menit. Sentrifus

Penelitian fagositosis makrofag peritoneum dengan Lateks yaitu untuk mengetahui jumlah makrofag yang memfagosit maupun yang tidak memfagosit serta jumlah lateks yang difagosit oleh makrofag. Data yang diperoleh tersebut dipakai oleh peneliti untuk menghitung kapasitas, aktivitas, dan indeks fagositosis. Pengamatan terhadap makrofag yang memfagositosis partikel lateks secara in vitro dilakukan dengan menggunakan mikroskop cahaya perbesaran 100x dan 400x. Warna biru keunguan yang muncul pada makrofag dengan kecepatan 2000 rpm selama 5 menit kemudian supernatan dibuang. Lateks yang telah mengandung serum kemudian dilarutkan dalam medium RPMI atau PBS. Sel makrofag dicuci $3 x$ dengan medium RPMI lalu ditambah Lateks sebanyak $200 \mu 1 /$ sumuran dan diinkubasi dalam inkubator $\mathrm{CO}_{2}$ suhu $37{ }^{\circ} \mathrm{C}$. Penambahan lateks kedalam sumuran berisi sel makrofag tersebut dilakukan dengan 5 perlakuan yaitu : (1) Sel makrofag ditambah lateks tanpa serum dengan waktu inkubasi selama 60 menit (2) Sel makrofag ditambah lateks yang mengandung serum dengan waktu inkubasi selama 60 menit, (3) Sel makrofag ditambah lateks yang mengandung serum dengan waktu inkubasi selama 45 menit, (4) Sel makrofag ditambah lateks yang mengandung serum dengan waktu inkubasi selama 30 menit, (5) Sel makrofag ditambah lateks yang mengandung serum dengan waktu inkubasi selama 15 menit, Selesai inkubasi sel di cuci $3 x$ menggunakan PBS lalu dikeringkan. Sel ditambah larutan fiksatif kemudian dikeringkan, selanjutnya dilakukan pengecatan dengan giemsa. Pengamatan dilakukan menggunakan mikroskop cahaya perbesaran 100x dan 400x. Hasil penelitian berupa hasil pengamatan yang terlihat dengan banyaknya makrofag yang memfagosit lateks tiap perlakuan terhadap lama waktu inkubasi.

\section{HASIL DAN PEMBAHASAN}

karena adanya pengecatan dengan pewarna Giemsa, sedangkan lateks akan terlihat bentuknya berupa butiran-butiran bulat.

Hasil pengamatan menunjukkan bahwa terdapat perbedaaan antar masingmasing perlakuan. Perlakuan pertama adalah perlakuan sesuai prosedur yang sudah baku yang berfungsi sebagai pembanding terhadap perlakuan lainnya, yaitu makrofag ditambah lateks tanpa serum dan di inkubasi selama 60 menit tetapi makrofag mengalami kendala tidak memfagosit lateks. 
Perlakuan (1) dapat dilihat pada Gambar 1 berikut :

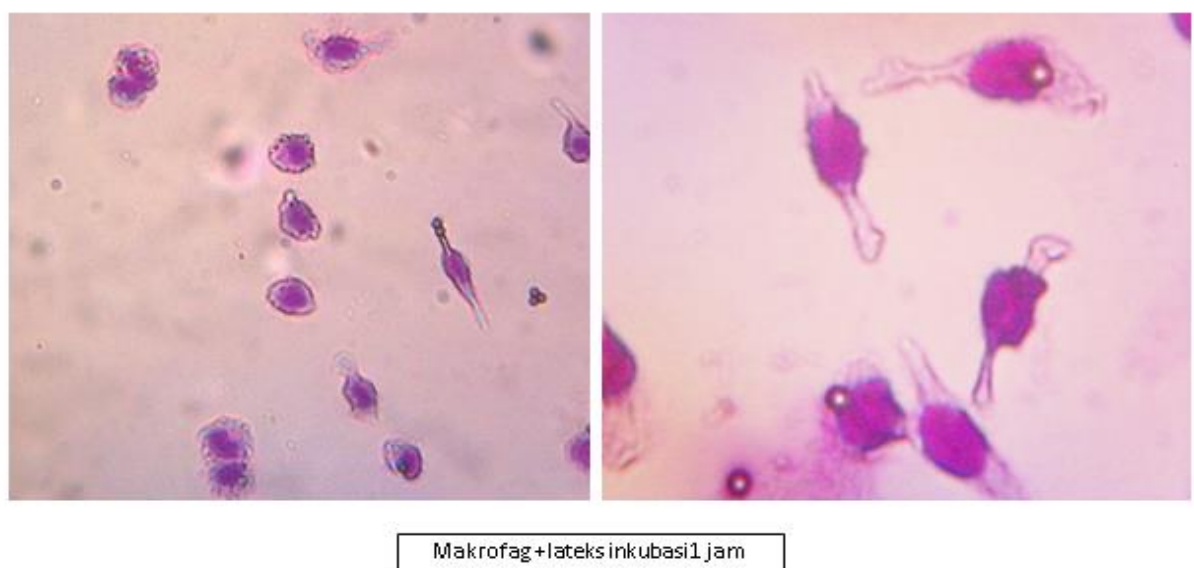

Gambar 1. Makrofag + lateks tanpa serum diinkubasi selama 60 menit

Perlakuan (1) menunjukkan bahwa proses fagositosis dengan lateks saja tanpa penambahan serum dan diinkubasi selama 1 jam atau 60 menit terlihat makrofag banyak yang tidak memakan/memfagosit lateks. Makrofag hanya memfagosit 1-2 lateks saja sedangkan makrofag yang lain kosong tidak ada lateks yang difagosit. Hal ini mempersulit pembacaan fagositosis lateks untuk pengolahan data selanjutnya.

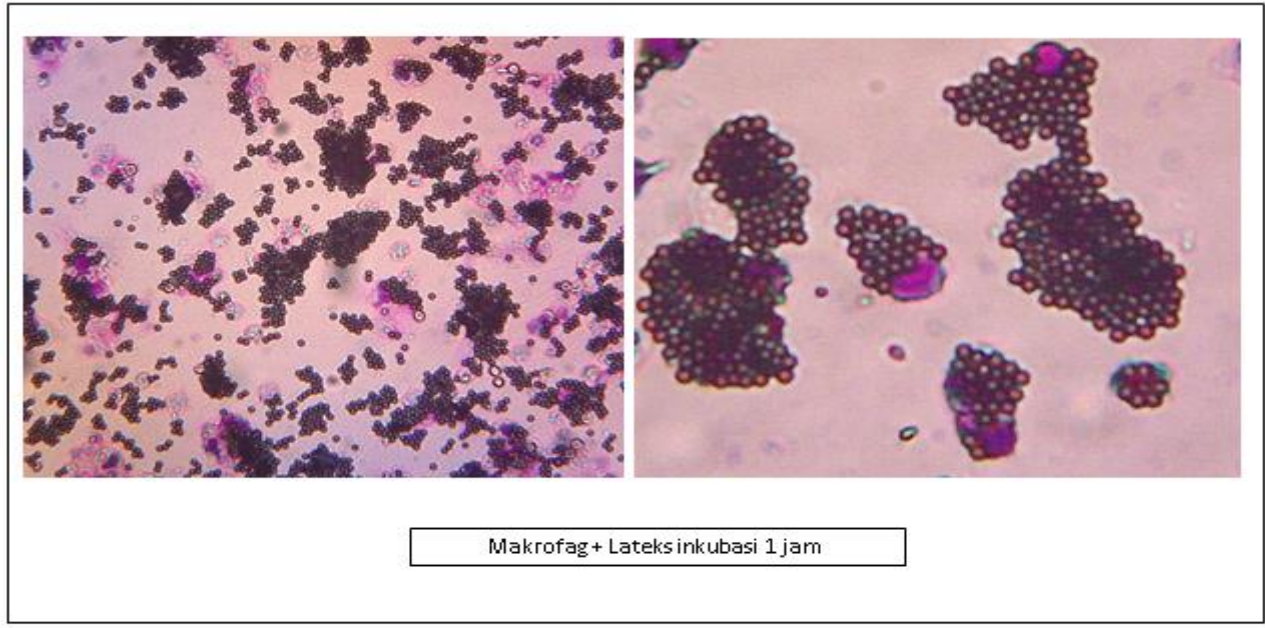

Gambar 2. Makrofag + lateks yang mengandung serum diinkubasi selama 60 menit,

Perlakuan (2) fagositosis makrofag dengan penambahan lateks yang mengandung serum dan diinkubasi selama 60 menit ditunjukkan pada Gambar 2 berikut.

Perlakuan (3) fagositosis makrofag dengan penambahan lateks yang
Perlakuan (2) menunjukkan bahwa lateks yang difagosit makrofag terlalu banyak bahkan menutupi seluruh sel makrofag sehingga menyulitkan pembacaan data fagositosis.

mengandung serum diinkubasi selama 45 menit dapat dilihat pada Gambar 3 berikut: 


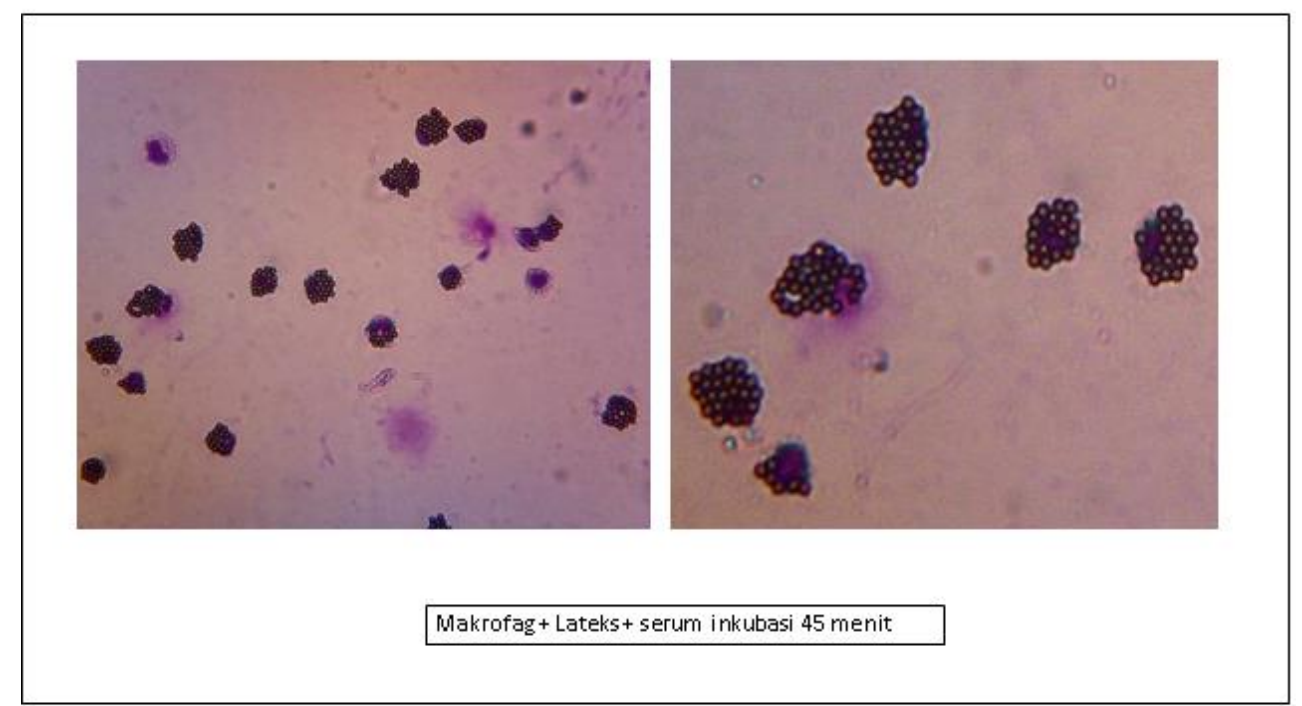

Gambar 3. Makrofag + lateks yang mengandung serum diinkubasi selama 45 menit.

Perlakuan (3) menunjukkan bahwa lateks yang difagosit makrofag masih terlalu banyak bahkan sebagian menutupi sel makrofag sehingga masih menyulitkan pembacaan untuk mendapatkan data fagositosis.

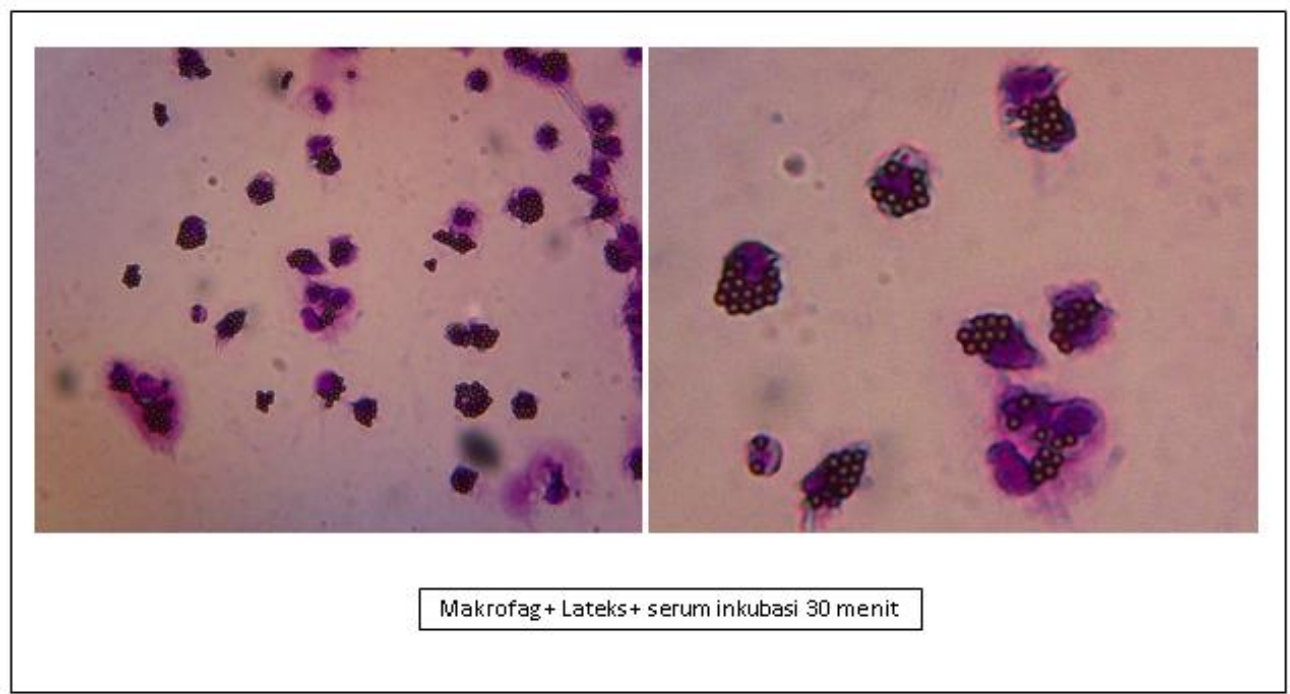

Gambar 4. Makrofag + lateks yang mengandung serum diinkubasi selama 30 menit.

Perlakuan (4) fagositosis makrofag dengan penambahan lateks yang mengandung serum dan diinkubasi selama 30 menit ditunjukkan dengan Gambar 4 :

Perlakuan (4) sesuai Gambar 4. menunjukkan bahwa lateks yang difagosit oleh makrofag masih banyak tetapi tidak sampai menutupi sel makrofag sehingga sudah tidak menyulitkan pembacaan data fagositosis.

Perlakuan (5) fagositosis dengan penambahan lateks yang mengandung serum dan diinkubasi selama 15 menit dapat dilihat dengan Gambar 5 berikut : 


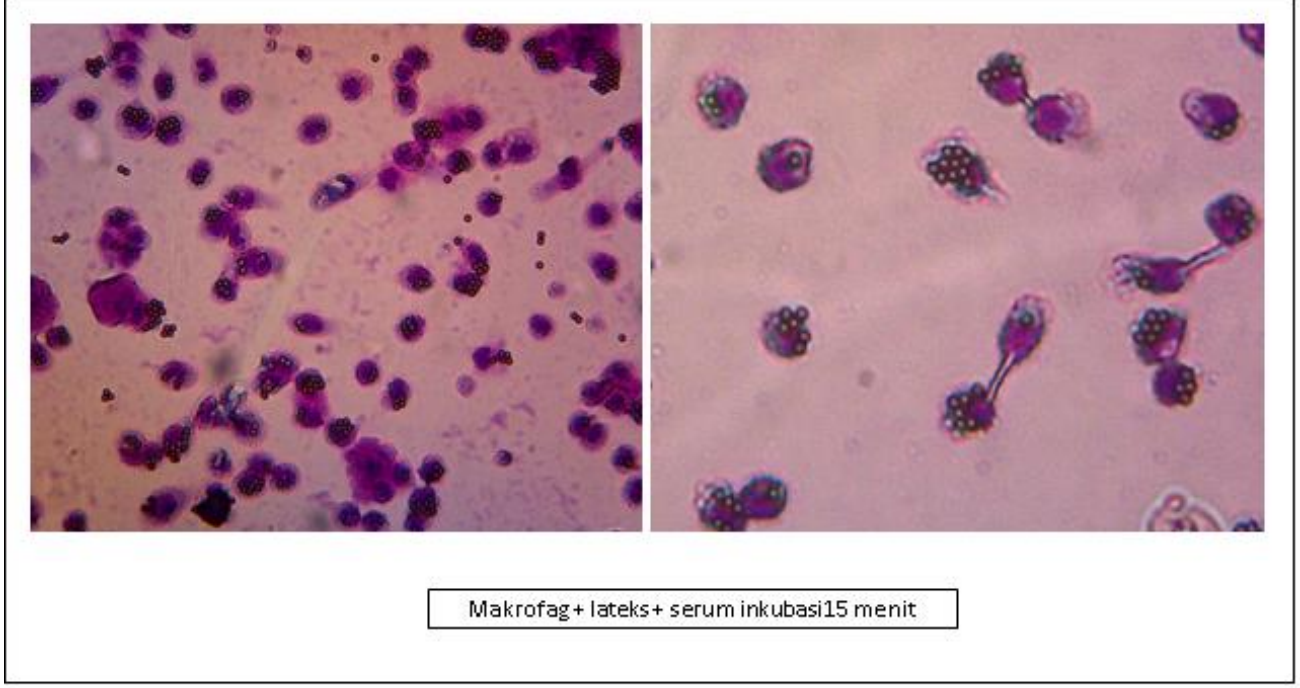

Gambar 5. Makrofag + lateks yang mengandung serum diinkubasi selama 15 menit.

Perlakuan (5) menunjukkan bahwa lateks yang difagosit makrofag dapat dihitung dengan mudah dan tidak terlalu banyak, tidak terlihat lateks yang menutupi makrofag sehingga tidak menyulitkan pembacaan data fagositosis.

Dari hasil pengamatan diatas dapat diketahui bahwa fagositosis makrofag apabila mengalami kendala makrofag tidak mau memfagosit lateks maka dapat ditambahkan serum sehat sesuai hewan coba yang digunakan saat penelitian. Penambahan serum bertujuan untuk mempermudah proses pelekatan lateks dengan makrofag. Waktu perlakuan pada saat penambahan lateks yang mengandung serum kedalam sel makrofag dan inkubasi selama 60 menit dan selama 45 menit masih sulit untuk diamati karena lateks yang difagosit oleh makrofag terlalu banyak dan menutupi sel makrofag. Perlakuan penambahan lateks

\section{KESIMPULAN}

Penambahan serum pada lateks merupakan salah satu solusi ketika penelitian fagositosis mengalami kendala yaitu tidak ada reaksi fagositosis antara makrofag dan lateks, sedangkan waktu inkubasi untuk proses

fagositosis antara makrofag dengan lateks yang mengandung serum dilakukan antara 15-30 menit.

\section{DAFTAR PUSTAKA}

yang mengandung serum kedalam sel makrofag dan inkubasi selama 30 menit dan selama 15 menit terlihat lateks yang difagosit oleh makrofag tidak terlalu banyak sehingga memudahkan pengamatan dalam mendapatkan data fagositosis untuk pengolahan perhitungan data selanjutnya, hal ini juga sesuai dengan hasil beberapa penelitian yang telah dilakukan di LPPT- UGM antara lain oleh Nurliyani (2016) dan Istini (2015). Penelitian fagositosis makrofag peritoneum tikus $S D$ menggunakan campuran lateks dan serum sebaiknya dilakukan waktu inkubasi antara 15-30 menit, setelah waktu inkubasi mencapai 15 menit dapat dilakukan pengecekan terlebih dahulu dengan mengamati dibawah mikroskop. Apabila dirasa kurang optimal, maka waktu inkubasi perlakuan dapat diperpanjang hingga 30 menit.

Abbas, A. and Lichtman, A. 2008 .Cellular and Molecular Immunology, Fifth edition, Elsevier Science, United States

Anonim, 2010, Lateks , Wikipedia Ensiklopodia bebas, diakses 17 Nopember 2015

Anonim, 2010, Serum Darah, Wikipedia Ensiklopodia bebas, diakses 17 Nopember 2015 
Baratawidjaja. 2006. Immunologi dasar. Jakarta: Fakultas Fakultas Kedokteran Universitas Indonesia

Istini. 2015. Pengaruh pemberian kefir susu kambing dan kefir susu kedelai terhadap aktivitas fagositosis makrofag tikus diabetes. Skripsi. Universitas Mercu Buana Yogyakarta.

Izzati S.A, Sumarno,Winarsih S. 2014, Peran Komplemen, Fagosit (Leukosit) dan Antibodi dalam Menurunkan Jumlah Mycobacterium tuberculosis, Majalah Kesehatan FKUB, vol.1, no 2 .

Kusmardi, Kumala S, Wulandari D, 2006, Pengaruh Pemberian Ekstrak Etanol Daun Johar (Cassia siamea Lamk.) terhadap Peningkatan Aktivitas dan Kapasitas Fagositosis sel Makrofag, Makara, Kesehatan, Vol 10, No 2, 89-93
Nurliyani. 2016. Efek Susu fermentasi Sinbiotik dengan Penambahan Glukomanan Porang (Amorphophallus onchophyllus) Terhadap Sifat Imunomodulator pada Tikus Sindroma Metabolik. Laporan Hasil Penelitian Unggulan Perguruan Tinggi. Universitas Gadjah Mada. Yogyakarta

Pratiwi L.C, 2014, Adhesi Porphyromonas Gingivalis pada Neutrofil yang diinkubasi ekstrak Kelopak Bunga Rosella (Hibiscus sabdariffa L.), Manakin Repository UNEJ

Ukhrowi U, 2011 , Pengaruh Pemberian Ekstrak Umbi Bidara Upas (Merremia mammosa) terhadap Fagositosis Makrofag dan Produksi Nitrit Oksida (NO) Makrofag Studi pada Mencit Balb/c yang Diinfeksi Salmonella typhimurium, tesis Program Pasca Sarjana UNDIP Semarang 